\title{
11. DISTRIBUTION AND PRESERVATION OF CENOZOIC PLANKTONIC FORAMINIFERS FROM THE CELEBES AND SULU SEAS, LEG 1241
}

\author{
A. J. Nederbragt ${ }^{2}$
}

\begin{abstract}
This paper presents the planktonic foraminifer biostratigraphy of the sites drilled during Ocean Drilling Program Leg 124 in the Celebes and Sulu Seas. It discusses preservation of foraminifers in pelagic sediments and in calcareous turbidites.

In the Celebes Sea, pelagic carbonates are only found in the Eocene and Oligocene at Site 770. The faunas are poorly preserved due to severe dissolution and offer little biostratigraphic detail. In the Sulu Sea, pelagic carbonates are found in the upper Pliocene and Pleistocene at Sites 768 and 769 and throughout the recovered sequence at the shallower Site 771. The foraminifer faunas from these sediments allow for recognition of most standard zones. Variations in preservation of pelagic foraminifer faunas with time are due to changes in the depth of the lysocline. Shifts to improved preservation at Sites 768 and 769 are synchronous in the upper Pliocene/Pleistocene and may be related to global sea-level cycles.

Planktonic foraminifers are also abundant in calcareous turbidites, which were deposited in both basins from the late Miocene onward. However, the turbidites are fine-grained, and biostratigraphic marker species are absent as a result of size-sorting during transport. In the Celebes Sea, shelf-derived material was a major component of early-late Miocene and middle Pliocene to early Pleistocene turbidites. Changes in the composition of the turbidites may correspond to global sea-level changes. In the Sulu Sea, a shift from shelf-derived material in Pliocene calcareous turbidites to a pelagic source in the Pleistocene may be related to subsidence of the Cagayan Ridge.
\end{abstract}

\section{INTRODUCTION}

During Leg 124, ODP drilled in the Celebes and Sulu Seas. The main objectives of this leg were to determine age and nature of the basement of these two marginal basins, and to trace their paleoceanographic history. To this purpose, five sites were drilled, two in the Celebes Sea and three in the Sulu Sea (Fig. 1). Deposition of carbonate-rich pelagic sediments occurred during certain times at all sites except at Site 767 in the Celebes Sea. But, as most of the sites were drilled in deep water, extensive parts of the recovered sequences were deposited below the calcite compensation depth (CCD). These two basins are close to land in an area of Neogene tectonic activity, which caused the influx of turbidites. Calcareous fossils are preserved in carbonate-containing turbidites. The distribution of the different types of foraminifer faunas, i.e., pelagic calcareous, displaced calcareous, and noncalcareous faunas deposited below the CCD, is shown in Figure 2. This paper documents the planktonic foraminifer biostratigraphy of pelagic carbonates and describes variations in the faunal composition of calcareous turbidites, to trace the source from which the material was derived.

\section{MATERIAL AND METHODS}

Within pelagic carbonates, two or three samples were taken in each core at regular intervals. Calcareous turbidites in those parts of the sequence that do not contain autochthonous carbonate were sampled wherever they occurred, to a maximum of three samples per core.

\footnotetext{
${ }^{1}$ Silver, E. A., Rangin, C., von Breymann, M. T., et al., 1991. Proc. ODP, Sci Results, 124: College Station, TX (Ocean Drilling Program).

2 Instituut voor Aardwetenschappen, Vrije Universiteit, de Boelelaan 1085, 1081 HV Amsterdam, the Netherlands.
}

All samples were washed over a $63-\mu \mathrm{m}$ sieve. For biostratigraphic purposes, samples were subsequently drysieved over a $125-\mu \mathrm{m}$ sieve, and scanned for the presence of biostratigraphic markers. In addition, the number of planktonic and benthic foraminifers and fragments of planktonic tests were counted in a representative split of the sieve fraction $>125 \mu \mathrm{m}$. The percentage of fragments and of benthic foraminifers is used as a measure of the extent of dissolution.

Foraminifers are abundant in calcareous turbidites, but most faunas contain few or no specimens in a sieve fraction $>125 \mu \mathrm{m}$. Therefore, estimates of the faunal composition in calcareous turbidites were made in the $>63-\mu \mathrm{m}$ sieve fraction. Large washed residues were split to obtain a representative subsample. The abundance of faunal components was estimated qualitatively, using the following criteria:

$$
\begin{aligned}
& \mathrm{VR}=\text { very rare, at most a few specimens per sample or } \\
& \text { split; } \\
& \mathrm{R}=\text { rare, at most } 1 \% \text { or } 2 \% \text { of the sample; } \\
& \mathrm{C}=\text { common (approx. } 2 \%-20 \%) ; \\
& \mathrm{A}=\text { abundant (approx. } 20 \%-80 \%) ; \\
& \mathrm{D}=\text { dominant, forming the bulk of the sample }(>80 \%) .
\end{aligned}
$$

The zonation used here follows that of Blow $(1969,1979)$ with ranges of species after Bolli and Saunders (1985) with additions from Stainforth et al. (1975) for the Neogene and from Toumarkine and Luterbacher (1985) for the Paleogene. In addition, changes in the predominant coiling direction of Neogloboquadrina acostaensis Blow and Pulleniatina spp. are assigned ages as given by Van Gorsel and Troelstra (1981). As the zonal marker Globorotalia truncatulinoides (d'Orbigny) is rare, occurring only in the upper Pleistocene, the lower boundary of Zone N22 is tentatively set at the change in coiling direction of Globorotalia menardii (Parker, Jones, and Brady) from predominantly dextral to sinistral. 


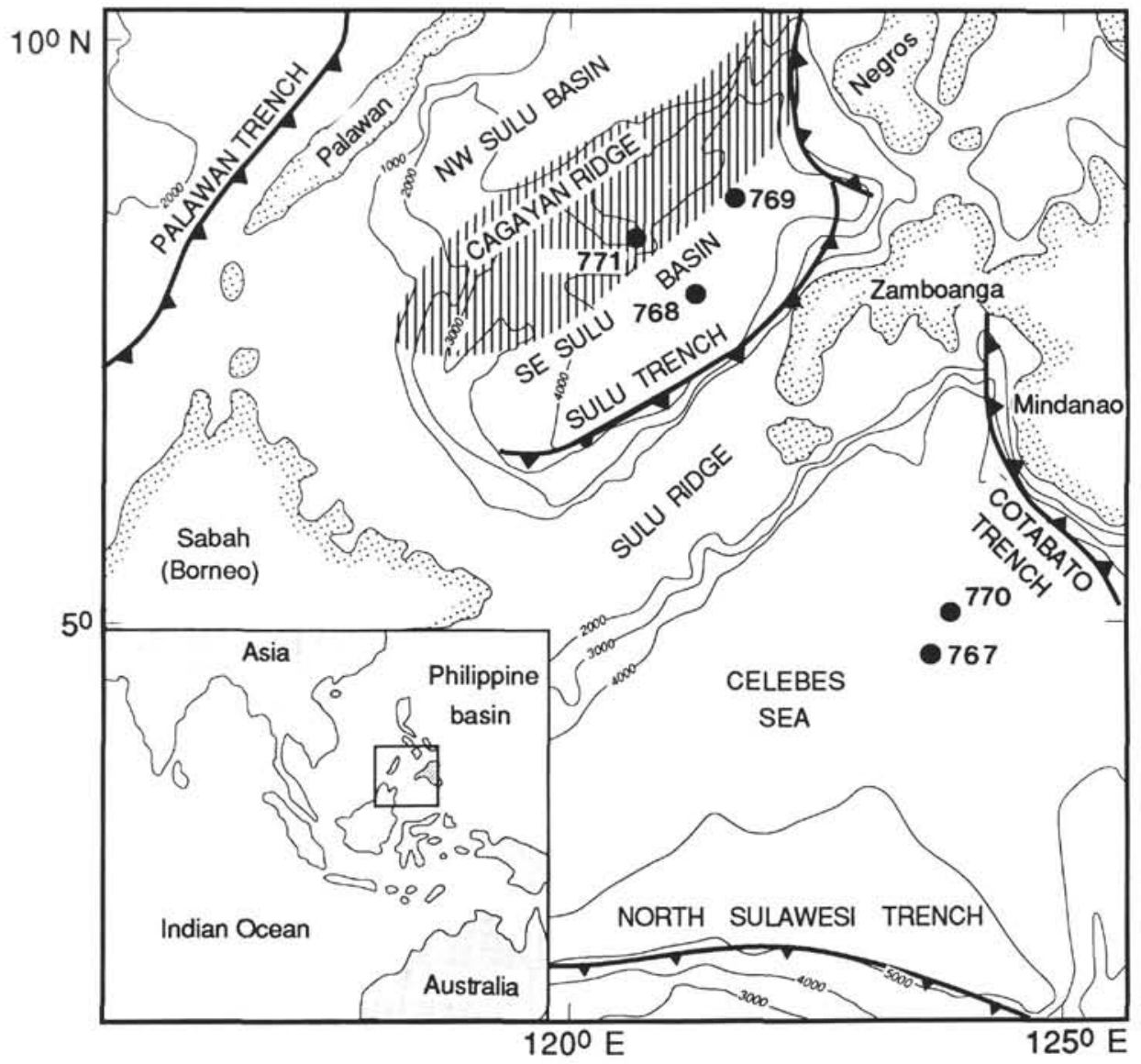

Figure 1. Map showing locations of Sites drilled during ODP Leg 124.

Biostratigraphic ages for sediments that were deposited below the CCD were obtained from calcareous fossils recovered in turbidites. Most of the floras and faunas were apparently displaced, with little or no reworking of older material. However, the planktonic foraminifer faunas in the calcareous turbidites are size-sorted and only rarely yielded age diagnostic species. For consistency in correlating between sites, stratigraphic ages presented herein are therefore based on the nannofossil and magnetostratigraphic zonation (Shyu et al., this volume), from which numeric ages were calculated in accordance with the time scale of Berggren et al. (1985).

\section{CELEBES SEA}

Two sites were drilled in the Celebes Sea, Site 767 in the center of the basin at a water depth of $4905 \mathrm{~m}$ and Site 770 on a bathymetric high, at a water depth of $4505 \mathrm{~m}$. Basement, which was reached at both sites, consists of mid oceanic ridge basalts, of late middle Eocene age (Rangin, Silver, von Breymann, et al., 1990). At Site 767 , basement is overlain by middle Eocene-to-Oligocene deep-sea red clays, which contain arenaceous foraminifers. The lateral equivalents of these clays at the shallower Site 770 are carbonate-bearing clays, containing calcareous faunas, which were deposited above, but close to the CCD.

\section{Biostratigraphy}

Planktonic foraminifers at Site 767 occur in two distinct types of faunas. Displaced faunas in upper Miocene to Pleistocene calcareous turbidites contain abundant and well-preserved foraminifers. Most samples almost exclusively contain specimens that fall within a $63-$ to $125-\mu \mathrm{m}$ sieve size range. The long-ranging Turborotalita quinqueloba (Natland), Turborotalita humilis (Brady), Globigerinita glutinata (Egger) and Globigerinita uvula (Ehrenberg) are the most frequent planktonic foraminifer species. In Miocene samples, they are accompanied by "zeoglobigerinids."

In addition, part of the samples from calcareous turbidites contain rare tests of larger specimens and their fragments, representing faunas that were deposited below the lysocline. Such dissolution-affected faunas also occur in some samples from Pleistocene hemipelagic deposits (Fig. 3). Globorotalia spp., Pulleniatina spp. and Sphaeroidinella dehiscens form the bulk of such faunas, accompanied by rare Globigerinoides spp. The few planktonic foraminifer ages that could be determined for the Site 767 samples are based on these dissolution resistant forms (Table 1).

The upper part of the section at Site 770 was not cored continuously and only a scattered record is available for the Miocene to Holocene. The carbonate content in all of the spot cores, Cores $124-770-1 \mathrm{R}$ to $7 \mathrm{R}$, is low (less than $0.5 \%$; Rangin, Silver, von Breymann, et al., 1990), indicating that the site has been below the CCD throughout this period. One sample from the core-catcher of Core 124-770A-4R contains a late Pliocene fauna of rare planktonic foraminifers showing signs of severe dissolution (Table 2). The preservation is the same as that of the dissolution resistant tests found at the deeper Site 767 .

The Eocene and Oligocene red clays found at Site 767 deeper in the basin are represented at Site 770 by pink to red nannoclays and marls, with up to $38 \%$ carbonate (Rangin, Silver, von Breymann, et al., 1990). Calcareous foraminifers are present in various intervals. The faunas are very poorly 


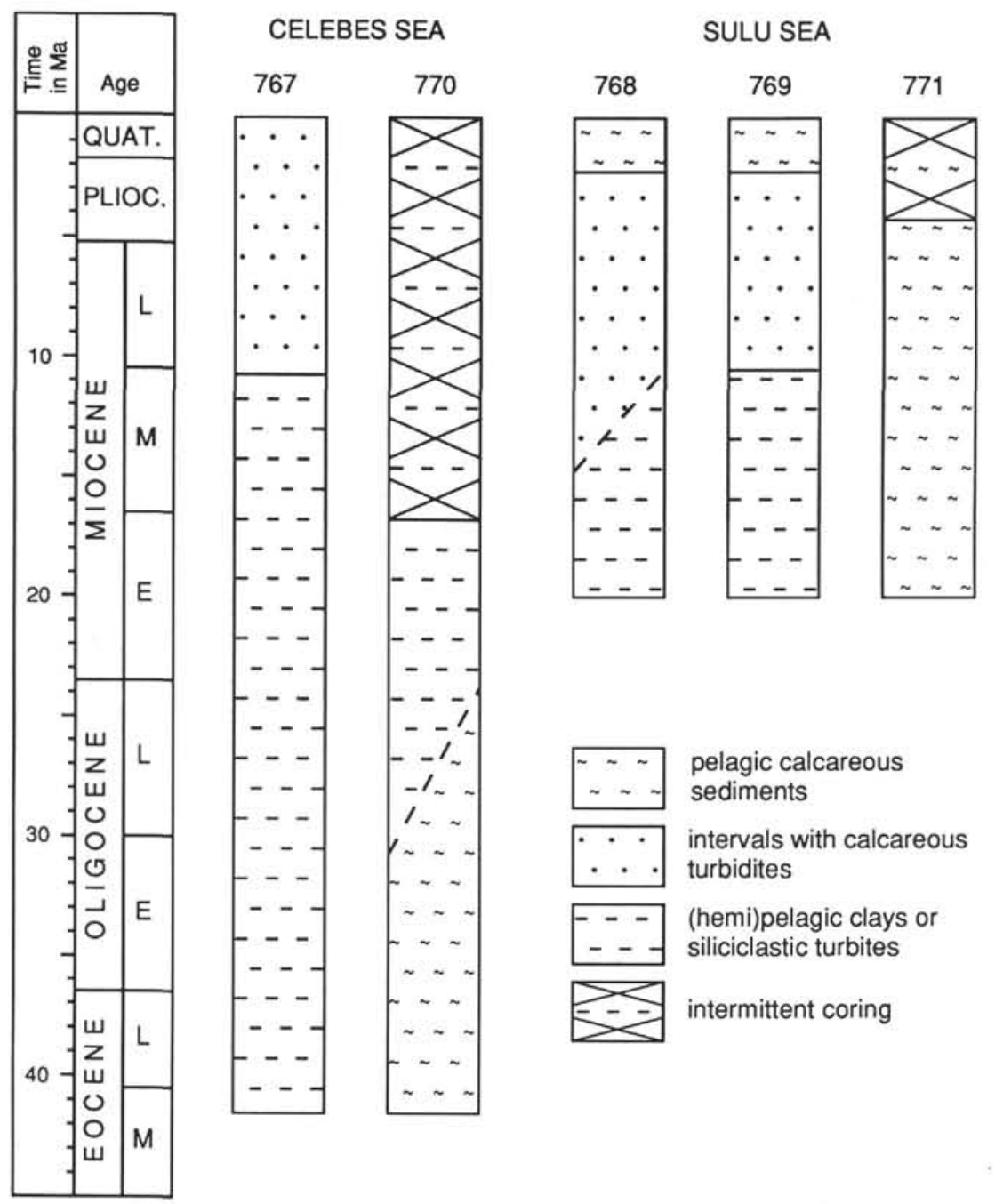

Figure 2. Distribution of pelagic and displaced calcareous microfossils in the Leg 124 sites in relation to sedimentology. Pelagic faunas are found in calcareous pelagic sediments, displaced faunas occur in carbonate-bearing turbidites. The clays and siliciclastic turbidites are barren or contain only noncalcareous microfossils.

preserved, showing signs of intense dissolution as well as diagenetic recrystallization. In most samples planktonic foraminifers are accompanied by numerous calcareous benthic foraminifers, arenaceous foraminifers, and ichthyoliths. The co-occurrence of Globigerina senni (Beckmann) and Turborotalia opima nana (Bolli), two dissolution-resistant species, in Sample 124-770-15R-4, 100-102 cm, and in the core catcher of Core 124-770B-15R (3.5 m above basement) allow for the recognition of the upper part of Zone P14 (upper middle Eocene; Table 2).

\section{Calcareous turbidites}

Calcareous turbidites at Site 767 contain faunas that are generally well preserved, even though they were deposited below the CCD (Rangin, Silver, von Breymann, et al., 1990). The rate of sedimentation was rapid enough that the calcareous material was buried before any dissolution could occur. Calcareous turbidites mostly by-passed the bathymetric high on which Site 770 is situated. The very rare and thin ones present are all indurated.

The main part of the sand-sized grains in all calcareous turbidites from Site 767 consists of planktonic and benthic foraminifers (Fig. 3). The benthic foraminifers include juveniles as well as common bolivinoides, cassidulinids, and discorbids. The frequencies of these groups relative to each other vary within the section; their distribution is described in more detail in Betzler et al. (this volume). The foraminifers are accompanied by other calcareous microfossils and skeletal debris of larger calcareous organisms. The most common calcareous microfossils are pteropods (mainly limacinids) and pelagic bivalves; both groups have aragonitic tests. Skeletal debris would have to be studied in thin-sections to determine its composition in any detail; in reflecting light, fragments of bryozoans, bivalves, and calcareous algae were identified occasionally.

Because Site 767 is located near the center of the basin, the calcareous turbidites are mostly distal and fine grained. Variations with time are observed: thin, rare calcareous turbidites occur in the Miocene and Pleistocene, whereas thicker and coarser grained turbidites are more frequent in the Pliocene (Rangin, Silver, von Breymann, et al., 1990). Changes in the composition of the faunas with time correspond only partially to changes in the thickness and frequency of the calcareous turbidites. Planktonic foraminifers are common to abundant throughout the section, benthic foraminifers and sand-sized 


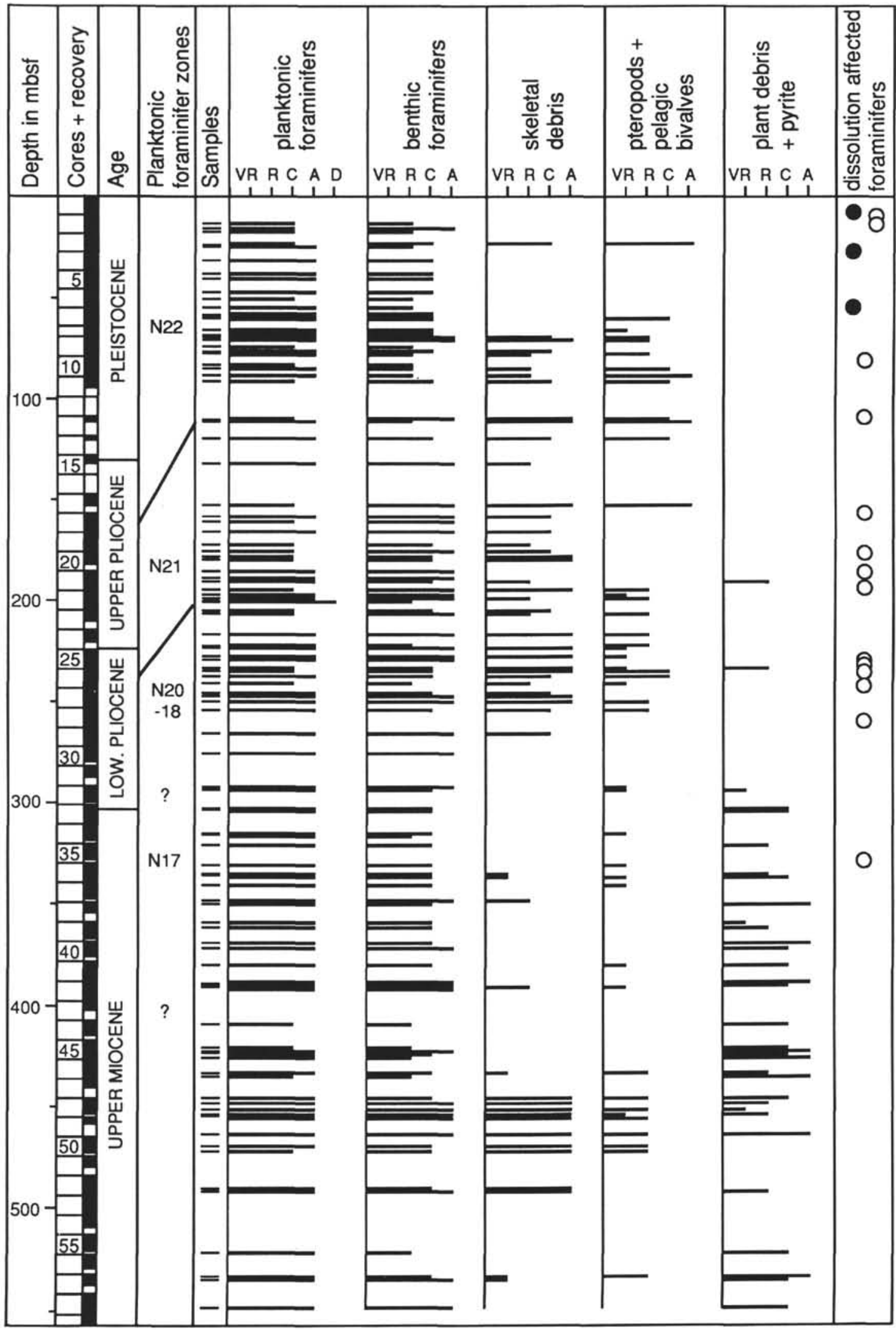

Figure 3. Composition of the sand-sized fraction of samples from calcareous turbidites at Site 767. The abundance of benthic foraminifers and skeletal debris in the lower part of the upper Miocene and mid-Pliocene-to- mid-Pleistocene sediments indicates that an important part of the displaced material in those intervals was derived from a shelf source. Planktonic foraminifer faunas in the calcareous turbidites consist almost exclusively of the tests of small, globular species. In addition, some upper Miocene to Pleistocene samples contain rare tests of large, dissolution-affected forms (indicated by circles in the last column). The presence of such forms in hemipelagic sediments is indicated by black dots. 
Table 1. Distribution of selected planktonic foraminifer species in dissolution-affected faunas at Site 767, and their biostratigraphic ages. As such faunas are always small and contain at most a few specimens of each species, only presence or absence of species are indicated. For stratigraphic position of samples, see Figure 3.

\begin{tabular}{|c|c|c|c|c|c|c|c|}
\hline $\begin{array}{c}\text { Sampled intervals } \\
\text { in cm } \\
124-767 \mathrm{~B} .\end{array}$ & 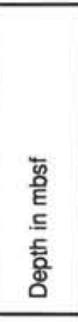 & 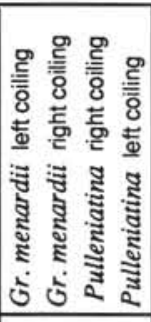 & 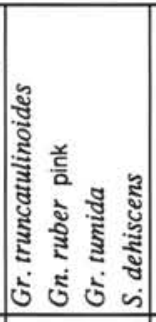 & 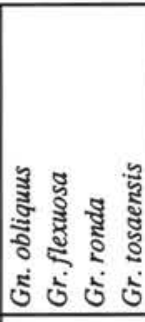 & 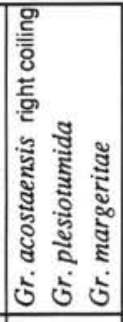 & 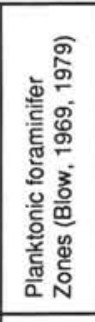 & Age \\
\hline $1 \mathrm{H}, \mathrm{CC}$ & 9.0 & & & & & \multirow{6}{*}{ N22 } & \multirow{6}{*}{ 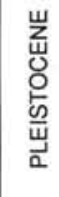 } \\
\hline $2 \mathrm{H}-3,85-87$ & 11.0 & & - & & & & \\
\hline$\frac{2 \mathrm{H}-6,123-125}{3 \mathrm{H}, \mathrm{CC}}$ & $\frac{15.2}{28.0}$ & $\div$ & $\bullet \bullet$ & & & & \\
\hline $\begin{array}{l}3 \mathrm{H}, \mathrm{CC} \\
6 \mathrm{H}, \mathrm{CC}\end{array}$ & $\begin{array}{l}28.0 \\
56.5\end{array}$ & $\bullet \quad:$ & - $\bullet$ & & & & \\
\hline $10 \mathrm{H}-2,44-46$ & 82.9 & & - & & & & \\
\hline $13 X-1,140-142$ & 1111.0 & $\bullet$ & $\mathrm{cf}$ & $\bullet$ & & & \\
\hline $\begin{array}{l}18 X-3,7-12 \\
20 X-3,52-55\end{array}$ & $\begin{array}{l}161.1 \\
180.8\end{array}$ & - & $::$ & cf $\bullet$ & & \multirow{3}{*}{ N21 } & \multirow{8}{*}{ 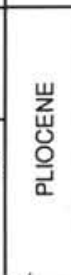 } \\
\hline $21 \times-5,65-67$ & 190.5 & - & $\bullet$ & - & & & \\
\hline $22 X-4,115-117$ & 199.2 & - & & & & & \\
\hline $26 x-2,76-78$ & 234.9 & - & - & - $\bullet$ & & \multirow{5}{*}{$\begin{array}{l}\mathrm{N} 19 / 20 \\
- \\
\mathrm{N} 18\end{array}$} & \\
\hline $26 X-4,7-9$ & 237.1 & -・ & & & - & & \\
\hline $26 \times-4,57-59$ & 237.7 & & - & & & & \\
\hline $26 X-6,90-92$ & 241.0 & & - & & & & \\
\hline $27 X-4,121-123$ & 247.9 & \multirow[t]{2}{*}{$\bullet \bullet$} & & \multirow[t]{2}{*}{$\bullet$} & \multirow{2}{*}{$:$ cf } & & \\
\hline $\begin{array}{l}29 X-3,113-115 \\
36 X-C C, 27-29\end{array}$ & $\begin{array}{l}265.5 \\
336.4\end{array}$ & & & & & N17 & MIOC. \\
\hline
\end{tabular}

Table 2. Distribution of selected planktonic foraminifer species at Site 770, and their biostratigraphic ages. Semiquantitative estimates of the relative importance of groups within the fauna give a measure of dissolution-related variations in preservation.

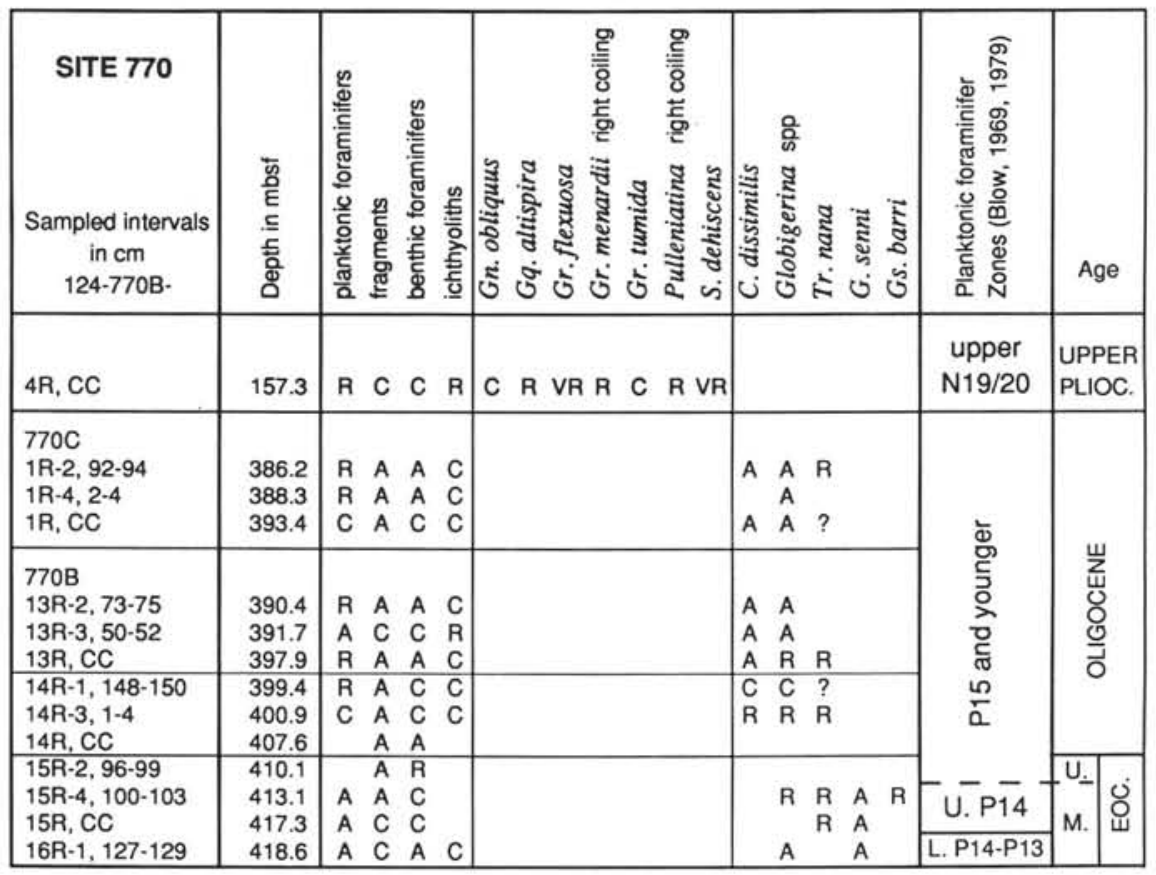

skeletal debris are most frequent in two intervals, 500-400 mbsf (lower part of the upper Miocene) and 260-60 mbsf (middle lower Pliocene to middle Pleistocene; Fig. 3). Aragonitic microfossils (pelagic bivalves, pteropods) are most abundant in the upper $150 \mathrm{~m}$ of the section (upper Pliocene and Pleistocene).

\section{SULU SEA}

Three sites were drilled in the Sulu Sea. Site 768 is located near the center of the basin at a water depth of $4385 \mathrm{~m}$. Sites 769 and 771 were drilled on tilted blocks on Cagayan Ridge, at water depths of 3644 and $2859 \mathrm{~m}$, respectively. The early 


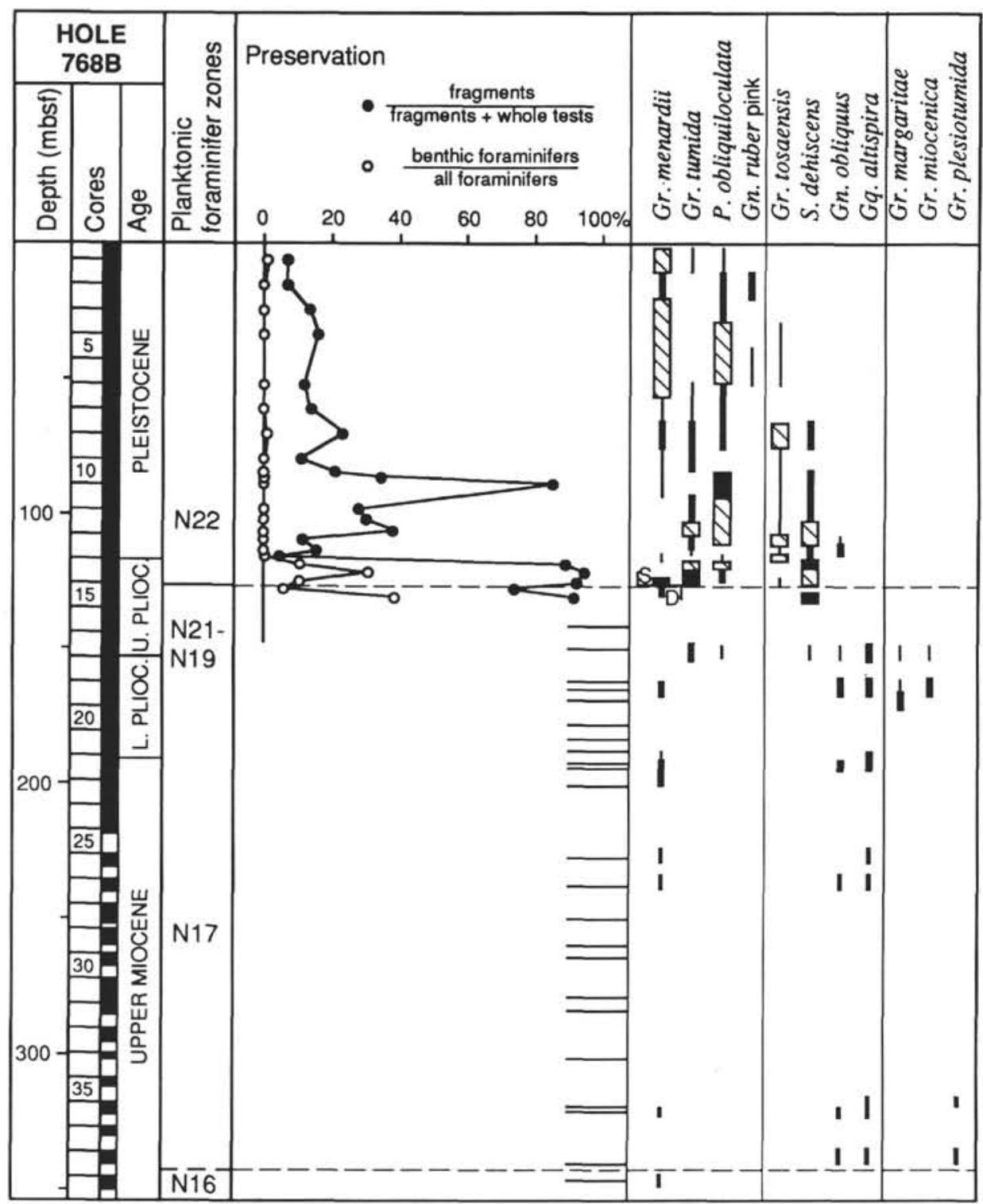

Figure 4. Preservation of pelagic foraminifer faunas at Site 768 and distribution of selected planktonic foraminifer species in pelagic as well as in displaced faunas. Horizontal lines in preservation columns indicate positions of calcareous turbidites that were sampled. Frequencies of foraminifer species are shown as semiquantitative estimates, with thin lines for very rare specimens, thick lines, rare; hatched bars, common; and black bars, abundant.

Neogene history of Sites 768 and 769 are comparable. Although they were below the CCD (Rangin, Silver, von Breymann, et al., 1990), calcareous microfossils are preserved in Miocene and younger turbidites. At both Sites, calcareous turbidites are less frequent than in the Celebes Sea and preservation of the faunas they contain is relatively poor. A number of turbidites are indurated to the extent that they yielded no faunas at all. Deposition of pelagic carbonate started during the Pliocene at Sites 768 and 769; the top of the section consists of marls, interbedded with thin volcaniclastic and calcareous turbidites. The depositional sequence at Site 771 consists of nannofossil marls and clays, without turbidites, and appears to have been above the CCD throughout its history.

\section{Biostratigraphy}

The two deep sites 768 and 769 have pelagic carbonate deposits only in the Pliocene and Pleistocene sediments. At Site 768 , the deepest sample with a pelagic foraminifer fauna, Sample 124-768B-15H-4, 98-100 cm, at a depth of $133 \mathrm{mbsf}$, belongs to the uppermost part of Zone $\mathrm{N} 21$; the change from predominantly right-coiling $\mathrm{Gr}$. menardii to left coiling occurs $4 \mathrm{~m}$ higher in the section (Fig. 4). The deepest pelagic foraminifer fauna from Site 769 , Sample 124-769B-14H-4, 21-23 cm, at $124.1 \mathrm{mbsf}$, is slightly older than at Site 768, (Fig. 5; compare Fig. 4). It is found some $20 \mathrm{~m}$ below the change in predominant coiling direction of G. menardii, and is tentatively placed in Zone N19/N20 based on the absence of $G$. tosaensis. 


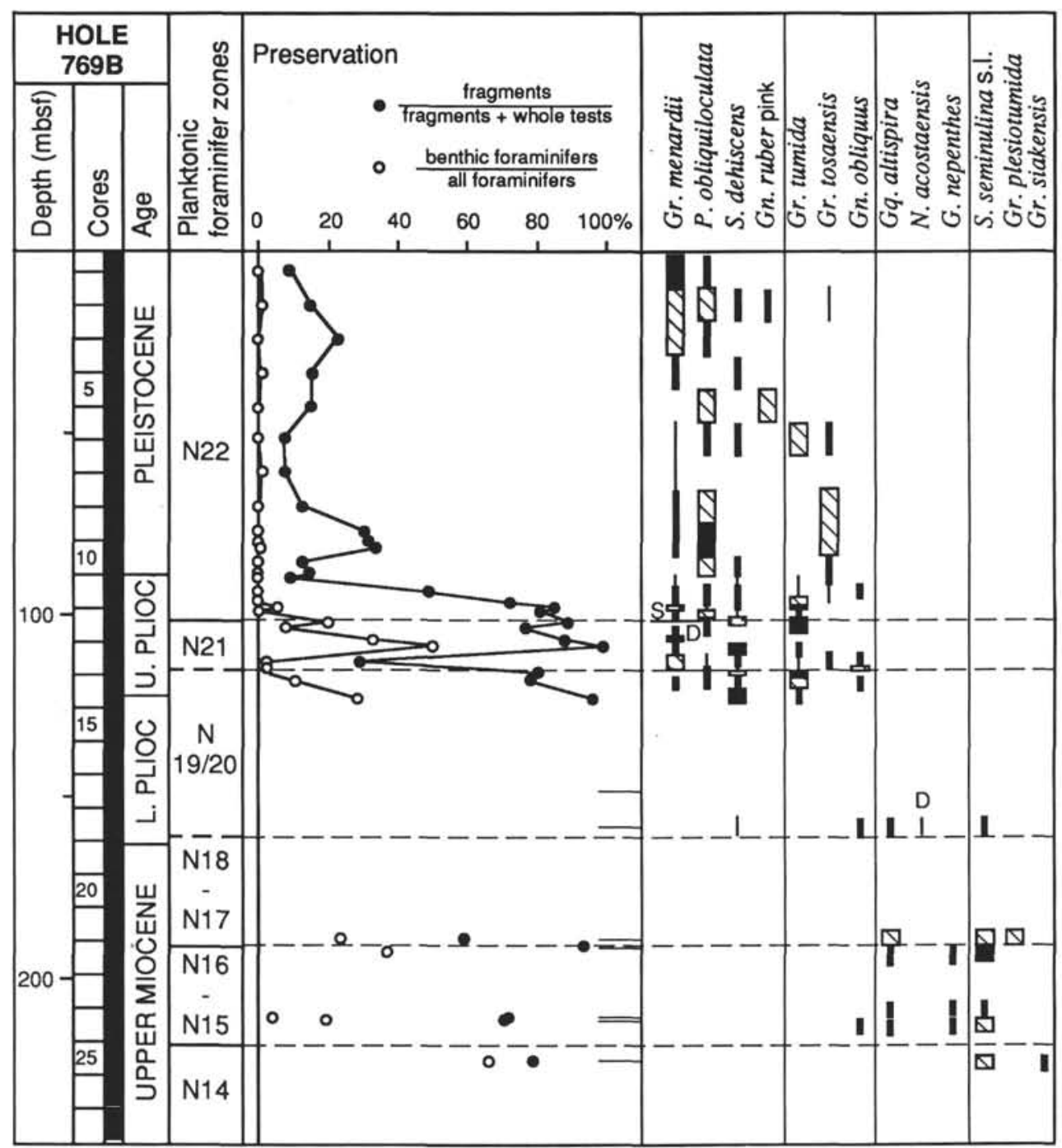

Figure 5. Preservation of foraminifer faunas at Site 769 and distribution of selected planktonic foraminifer species from pelagic faunas as well as in turbidites. For explanation of symbols, see Figure 4.

Calcareous foraminifers in lower Pliocene and older sediments at both deep sites are found only in turbidites. At Site 768 , calcareous turbidites contain faunas in which small tests of long-ranging planktonic species form the main planktonic component. Age diagnostic species are rare (Fig. 4). Calcareous turbidites are rare at Site 769 , and most are indurated. However, thin bioturbated calcareous turbidites, which occur in Cores $124-768 \mathrm{~B}-21 \mathrm{H}$ to $25 \mathrm{X}$ (190-230 mbsf), give foraminifer faunas that show severe signs of dissolution but are otherwise well preserved (Fig. 5). Dissolution-resistant species are concentrated, i.e., species that at the other localities do not occur in turbidites. Sphaeroidinellopsis seminulina (Schwager) is the most abundant form, but the occurrence of Globorotalia siakensis LeRoy, Globigerina nepenthes Todd, and Globorotalia plesiotumida Blow and Banner in this interval allows for tentative subdivision of Zones N14, N15/N16, and N17, respectively (Fig. 5).

Only one core was taken in the upper $144 \mathrm{~m}$ of the section at Site 771. Below that level, coring was continuous, although generally with poor recovery. The section gives a continuous middle Miocene to lower Pliocene planktonic foraminifer biostratigraphic record (Zones N18 to N8; Fig. 6). The fora- minifer faunas show varying degrees of fragmentation; Sphaeroidinellopsis spp. are the most abundant planktonic foraminifers in most samples. To some extent, observed species ranges may have resulted from varying degrees of preservation. For example, representatives of the Globorotalia fohsi lineage are rare (too rare to subdivide Zones N10 to $\mathrm{N} 12$ ), but occur mostly in an interval of slightly better preservation. The absence of Orbulina spp. in Core 124$770 \mathrm{~A}-9 \mathrm{R}$ and in the upper part of $-10 \mathrm{R}$ can be attributed to selective dissolution. The lower boundary of Zone N9, defined by the first appearance of Orbulina suturalis Brönnimann, is placed in the top of Core 124-770A-10R; the better-preserved faunas below this level contain relatively common Praeorbulina spp., indicating that the absence of Orbulina spp. in those samples is primary.

\section{Preservation of Pliocene/Pleistocene Foraminifer Faunas}

Variations in the extent of fragmentation and the percentage of benthic foraminifers in the Pliocene/Pleistocene faunas at Sites 768 and 769 show that preservation improved in three or four intervals. To compare the timing of changes at both sites, the percentage of fragments of foraminifer tests and the 


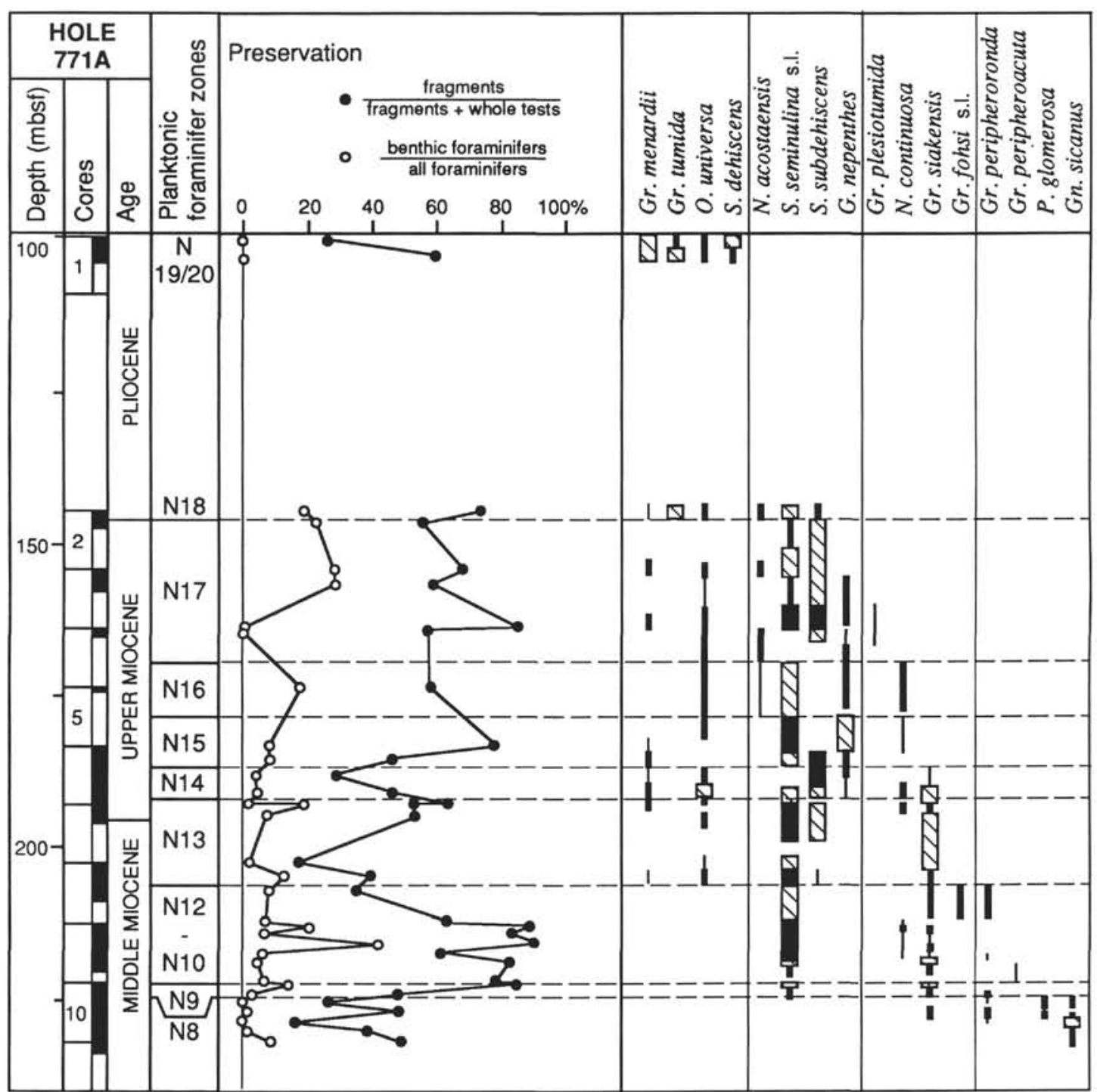

Figure 6. Preservation of foraminifer faunas at Site 771 and distribution of selected planktonic foraminifer species. For explanation of symbols, see Figure 4.

carbonate content of the sediments are plotted against linear time (Fig. 7). For each sample a numeric age was calculated through linear interpolation of sediment thickness between magnetic reversals. Ages and depth of magnetic reversals, as well as carbonate data are compiled from Rangin, Silver, von Breymann, et al. (1990).

\section{Calcareous Turbidites}

At Site 768, sporadic foraminifers are incorporated in lower upper Miocene siliciclastic turbidites, which were sampled below 400 mbsf (Fig. 8). Carbonate-rich turbidites in the middle of the upper Miocene (275-350 mbsf) are fine grained and yield only small sand-sized residues. Calcareous foraminifers and terrestrial material constitute equally important components in the sand-sized fraction of these samples. The frequency of calcareous turbidites as well as their thickness and grain size increased in the Pliocene. The presence of (recognizable) skeletal debris in turbidites from the uppermost Miocene and lower Pliocene indicates that an important component of these deposits is derived from a carbonate shelf. With time, the amount of shallow material decreased while the relative frequency of planktonic foraminifers increased (Fig. 8 ). The sand-sized fraction of calcareous turbidites within the Pleistocene marls consists almost exclusively of planktonic foraminifers accompanied by very rare benthic specimens (Fig. 8). The apparent scarcity of calcareous turbidites in the upper Pliocene and Pleistocene is mainly an artifact of sampling. The pelagic calcareous sediments were sampled at regular intervals, disregarding sedimentologic variations, while below, samples were taken in calcareous turbidites only.

\section{DISCUSSION}

\section{Biostratigraphic Resolution}

Foraminifer biostratigraphic results for the Leg 124 sites are mostly restricted to pelagic carbonates. In the turbidite sequences in the Neogene at Site 767 in the Celebes Sea and the Miocene to lower Pliocene at Sites 768 and 769 in the Sulu Sea, calcareous turbidites are the only source of marine microfossils. For these parts of the sections, nannofossils were used as the main biostratigraphic markers. First and last 


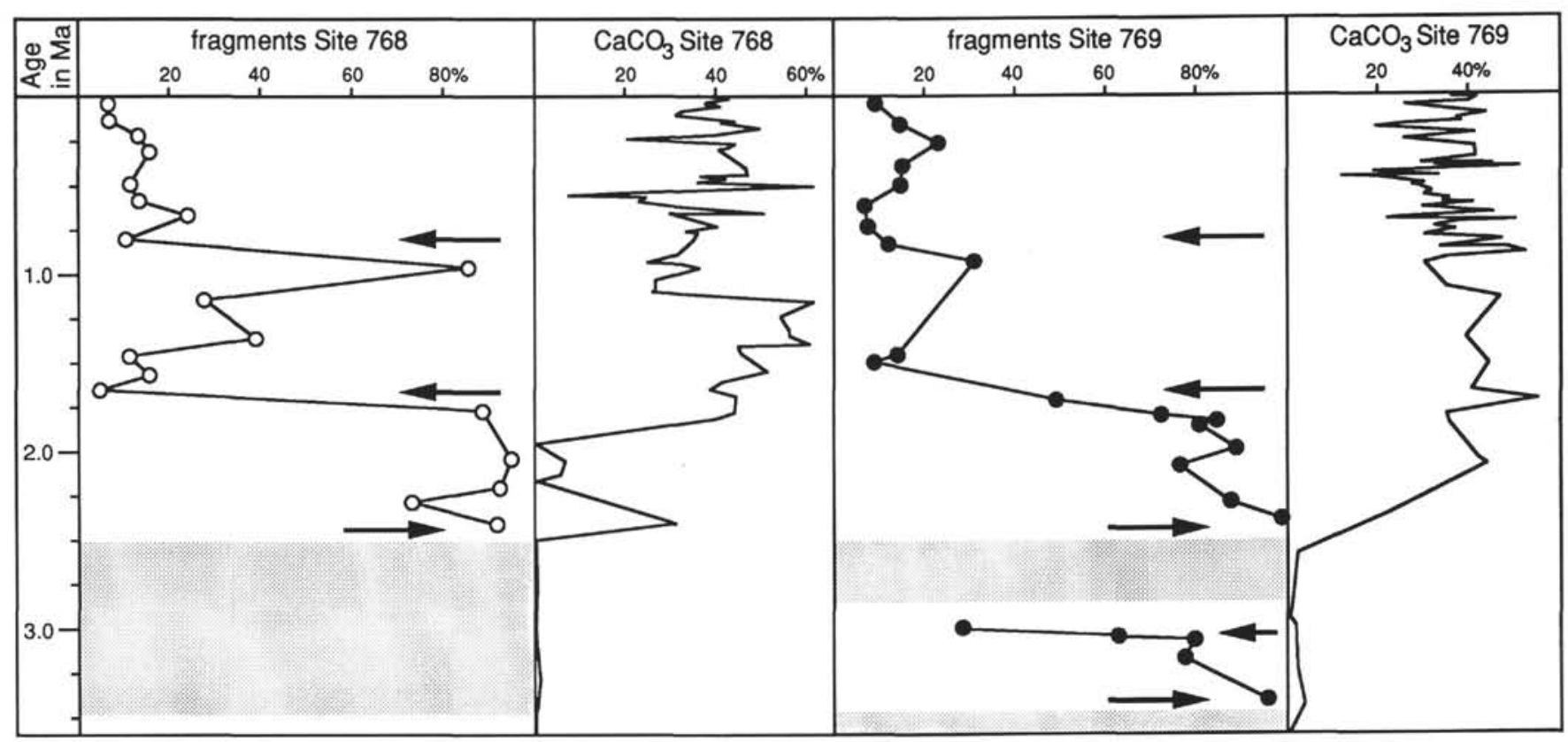

Figure 7. Percentage of foraminifer fragments in pelagic faunas and carbonate content of pelagic sediments at Sites 768 and 769 against linear time. Sample depth was converted to numeric ages by linear interpolation between nearest magnetic reversals; age and depth of magnetic reversals and carbonate data after Rangin, Silver, von Breymann, et al. (1990). Shaded areas represent clay intervals without pelagic foraminifer faunas; arrows indicate times that preservation improved. Note that changes in preservation between 0.8 and 2.4 Ma are synchronous at the two sites.

occurrences are consistent with the published record, which suggests that the material in the turbidites is displaced, with at most minor amounts of reworked material from older sediments. The fact that age-diagnostic foraminifers are at best rare can be attributed to size- and (or) weight-sorting during transport. Most of the turbidites are fine-grained, with few foraminifers in a sieve fraction $>125 \mu \mathrm{m}$. The planktonic foraminifer faunas consist almost exclusively of adults of small, globular species, most of which have long stratigraphic ranges, while the ranges of others are not well documented. A few coarser grained turbidites in the Pliocene at Sites 767 and 768 contain foraminifers with larger tests, but the majority of those are specimens with relatively thin shells (e.g., $G$. glutinata). Most biostratigraphic marker species are large species with heavy calcified tests and would settle in the more proximal parts of a turbidite.

The origin of the dissolution-affected faunas in the uppermost Miocene to Pleistocene at Site 767 and in the Pliocene core from Site 770 is not clear. The poor preservation is typical of deposition well below the lysocline but above the CCD. Although Site 767 appears to have been below the CCD during its entire history, the rate of sediment accumulation may have been high enough to allow remains of calcareous faunas to be buried before they were completely dissolved. Yet most dissolution-affected faunas were found incorporated in calcareous turbidites, including in thick ones for which burrowing from overlying sediments can be excluded. Thus at least part of those faunas are displaced also. Probably they were incorporated into turbidites during the last stages of transport.

\section{Calcareous Turbidites}

The faunal composition of the calcareous turbidites gives information on the source from which the material was derived. The number of benthic foraminifers relative to planktonic foraminifers in situ is a function of water depth. The number of benthic foraminifers is highest in shallow water, but decreases with increasing depth. The skeletal material is mostly derived from reef-related organisms. Large amounts of benthic foraminifers and skeletal debris in a calcareous turbidite indicate that an important part of the material is derived from a shelf source; an increase in planktonic foraminifers would occur if turbidites originated from greater water depths.

Long-term variations in the composition of calcareous turbidites in the Celebes Sea may be related to changes in the global sea level, with increased erosion of calcareous shelf deposits during lowstands. The increase in material derived from deep sources in the uppermost Miocene at Site 767 is shown as an increase in the number of planktonic foraminifers (Fig. 3). It corresponds to a period of overall high sea level (Haq et al., 1987). The increase of shelf-derived material in lower Pliocene turbidites may correspond to a major drop of sea level at $3.8 \mathrm{Ma}$. In the sequence stratigraphy model for clastic sedimentary environments (Posamentier et al., 1988), a fall of sea level causes erosion on the shelf, and the material is transported into the basin. The shelf builds out during a highstand, and the basin receives pelagic sediments. Any turbidites formed during a highstand are probably generated on the slope as most of the sediments on the shelf are trapped there. In such a setting, turbidites generated during a sea-level highstand would contain abundant planktonic foraminifers (deep source), while those formed during a lowstand would contain abundant benthic foraminifers (shelf source). The relation of reef-derived turbidites with sea level is thought to be the opposite. Production on a carbonate platform, and thus shedding, would be high during times of high relative sea level, causing an increase in the amount of reef-debris in turbidites (Droxler and Schlager, 1985; Reymer et al., 1988). However, the predominance of foraminifers in the Site 767 turbidites suggests that the contribution of reef-derived debris to the source material was relatively minor. Possibly, the source area was a calciclastic environment with patch reefs 


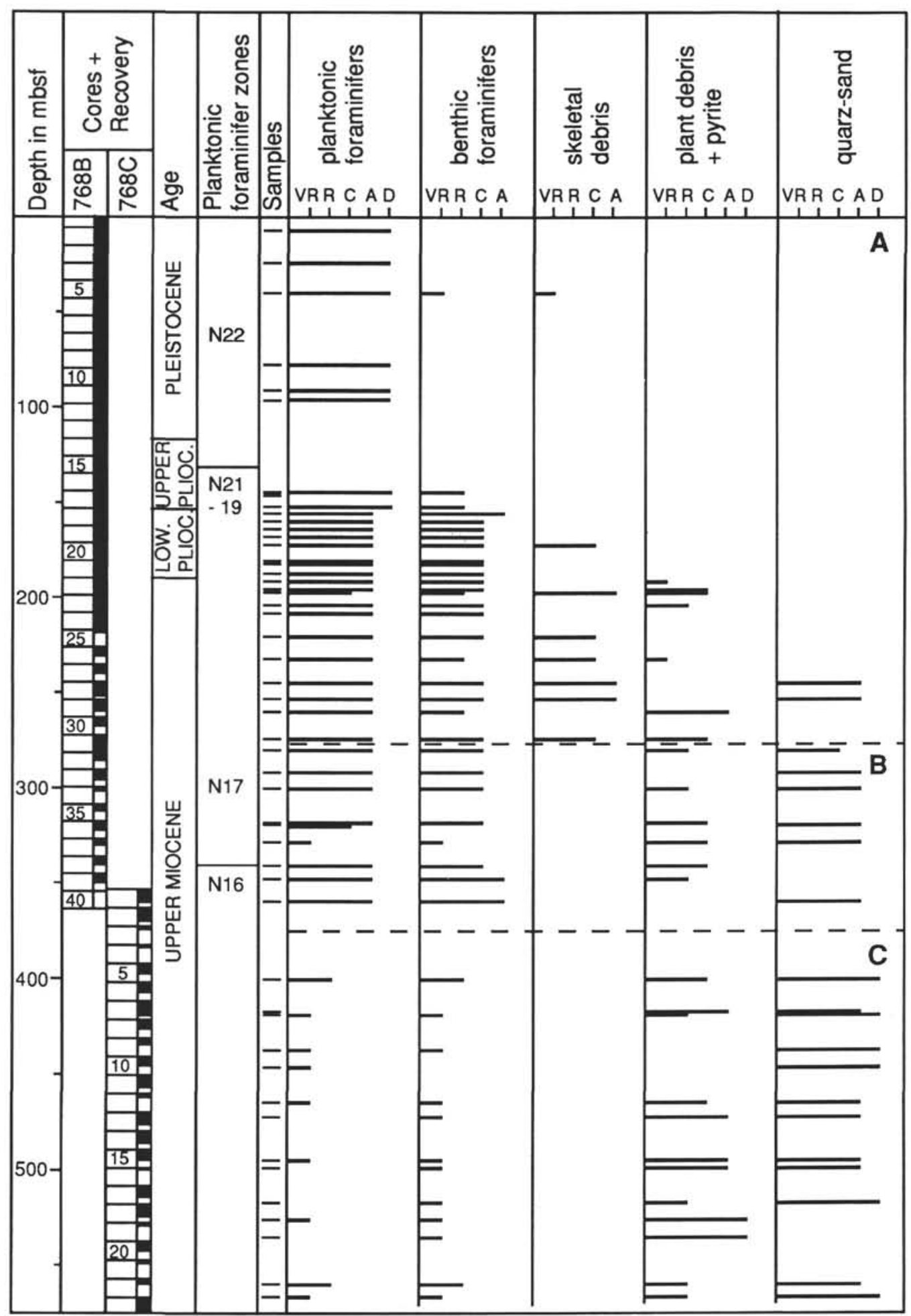

Figure 8. Composition of the sand-sized fraction of samples from foraminifer-bearing turbidites at Site 768. Note change with time, with rare foraminfers incorporated in terrestrial material (quartz and plant debris) in the lower part of the upper Miocene (C). Fine-grained calcareous turbidites, with foraminifers mixed with terrestrial material (B) and calcareous faunas with frequent benthic foraminifers and skeletal debris in the lower Pliocene grade to planktonic foraminifer sands in the Pleistocene (A). The apparent scarcity of Pleistocene calcareous turbidites is an artifact of sampling density. 
only, in which foraminifers formed the bulk of the sand-sized particles. Such a sedimentary setting would react to changes of sea level in approximately the same way as the siliciclastic environments on which the sequence stratigraphy model is based. A possible relation of short-term variations in the composition of the Site 767 calcareous turbidites with thirdorder cycles of sea level is discussed in Betzler et al. (this volume).

The trend in the composition of calcareous turbidites in the Sulu Sea is roughly comparable to that in the Celebes Sea. Upper Miocene turbidites are fine-grained, Pliocene ones are thicker, more frequent, and contain large amounts of skeletal debris and numerous benthic foraminifers; benthic foraminifers are again rare in Pleistocene turbidites (Fig. 8). However, the increase of material derived from a deep-water source in the Pliocene to Pleistocene seems much more pronounced at Site 768 than at Site 767. In the Sulu Sea, the bulk of the sand-sized fraction of Pleistocene calcareous turbidites consists of planktonic foraminifers. Benthic foraminifers form at most $1 \%$ or $2 \%$ of the faunas in these turbidites, a percentage that in pelagic faunas would indicate a bathyal depth of deposition. The shift from a shelf source to bathyal source suggests that the tectonic history of the Cagayan Ridge controlled the composition of calcareous turbidites in the Sulu Sea. Miocene and Pliocene reef carbonates have been dredged from present water depths of more than $3000 \mathrm{~m}$ (Kudrass et al., 1990), suggesting that at least part of Cagayan Ridge has subsided very rapidly during the Neogene. The calcareous turbidites could be directly derived from the Cagayan Ridge, in which case the composition reflects subsidence of the source area itself or the source shifted from one area to another as the geometry of the ridge changed.

\section{Variations in Preservation of Pelagic Foraminifer Faunas}

The Sulu Sea sites could potentially offer a record of the history of carbonate sedimentation and dissolution in that basin, but the actual magnitude of any changes in the $\mathrm{CCD}$ will remain uncertain in the absence of paleobathymetric control. The subsidence history of a back-arc basin cannot be reliably estimated, while the tectonic history of the Cagayan Ridge, on which the two shallower sites are situated, is not known in any detail.

The start of sedimentation of pelagic carbonate at Sites 768 and 769 during the late Pliocene (Fig. 7) registers a fall of the CCD in the basin that is probably related to a world-wide falling trend during the Pliocene/Pleistocene (van Andel, 1975). Shifts between barren intervals and those with foraminifer faunas follow the changes from carbonate-poor to carbonate-rich sediments. In addition, the fragmentation of foraminifers indicate repeated variations in preservation, which appear to have been synchronous at both sites (Fig. 7). The changes in the amount of fragments of foraminifer tests reflect changes in the depth of the lysocline. Periods of improved preservation (less fragments) started at both sites at around $0.8,1.6$, and $2.4 \mathrm{Ma}$. This suggests a relation with global sea-level changes, as sea level fell at the same ages (Haq et al., 1987). The decrease of fragmentation around $3.2 \mathrm{Ma}$ at Site 769 and the appearance of calcareous foraminifer faunas around $3.5 \mathrm{Ma}$ are at best in the same age-bracket as the next two sea-level cycle terminations ( $3.0 \mathrm{Ma}$ and $3.8 \mathrm{Ma}$; Haq et al, 1987). The difference in age could be real, or it could be due to lack of sample coverage.

Long-term global fluctuations in the CCD correspond to long-term sea-level changes (compare van Andel, 1975 and Haq et al., 1987), as the depth of the CCD is in part a function of the amount of carbonate that is deposited on the shelves (Berger and Winterer, 1974). During periods of high sea level, shelf area increases and more carbonate can be stored there, causing the CCD to rise due to depletion of the carbonate reservoir in the deep ocean. The semi-isolated nature of the Sulu Sea may have caused a correlation between short-term fluctuations of sea level and the CCD. The modern deepest connection to the surrounding oceans is to the northeast of Palawan (Fig. 1), and in the present situation the inflowing intermediate waters from the South China Sea form the deep water of the Sulu Sea (Frische and Quadfasel, 1990). Linsley et al. (1985) estimated that a fall of sea level of $100 \mathrm{~m}$ is enough to cut off the modern inflow from the South China Sea. This change would considerably alter the chemical and physical characteristics of the deep water in the Sulu Sea. Thus sea level is an important factor in controlling the oceanography of the Sulu Sea, which in turn influences the depth of the lysocline and the CCD. The spacing of the samples studied here indicate a correlation of foraminifer preservation with third-order sea-level cycles, which in the Pliocene and Pleistocene have a 0.8-Ma frequency (Haq et al., 1987). A more detailed sample coverage might show that preservation of foraminifers also varied with glacial -interglacial fluctuations.

\section{ACKNOWLEDGMENTS}

I am grateful to S. R. Troelstra for many helpful suggestions. Thanks are due the JOIDES Resolution crew and technicians and the ODP onshore staff for providing samples. The financial support of the Dutch Council for Seagoing Research (SOZ) allowed me to participate in ODP Leg 124.

\section{REFERENCES}

Berger, W. H., and Winterer, E. L., 1974. Plate stratigraphy and the fluctuating carbonate line. In Hsü, K. J., and Jenkyns, H. C. (Eds.), Pelagic Sediments on Land and Under the Sea: Spec. Publ. Int. Assoc. Sedimentol., 1:11-48.

Berggren, W. A., Kent, D. V., Flynn, J. J., and Van Couvering, J. A., 1985. Cenozoic geochronology. Geol. Soc. Am. Bull., 96:14071418.

Blow, W. H., 1969. Late middle Eocene to Recent planktonic foraminiferal biostratigraphy. In Brönniman, P., and Renz, H. H. (Eds.), Proc. First Int. Conf. Planktonic Microfossils, Geneva: Leiden (E. J. Brill), 1:199-422.

1979. The Cainozoic Globigerinida: Leiden (E. J. Brill).

Bolli, H. M., and Saunders, J. B., 1985. Oligocene to Holocene low latitude planktonic foraminifera. In Bolli, H. M., Saunders, J. B., and Perch-Nielsen, K. (Eds.), Plankton Stratigraphy: Cambridge (Cambridge Univ. Press), 155-262.

Droxler, A. W., and Schlager, W., 1985. Glacial versus interglacial sedimentation rates and turbidite frequencies in the Bahamas. Geology, 13:799-802.

Frische, A., and Quadfasel, D., 1990. Hydrography of the Sulu Sea. In Rangin, C., Silver, E. A., von Breymann, M. T., et al., Proc. $O D P$, Init. Repts., 124: College Station, TX (Ocean Drilling Program), 101-104.

Haq, B. U., Hardenbol, J., and Vail, P. R., 1987. Chronology of fluctuating sea levels since the Triassic. Science, 235:1156-1167.

Kudrass, H. R., Müller, P., Kreuzer, H., and Weiss, W., 1990. Volcanic rocks and tertiary carbonates dredged from the Cagayan Ridge and the Southwest Sulu Sea, Philippines. In Rangin, C., Silver, E. A., von Breymann, M. T., et al., Proc. ODP, Init. Repts., 124: College Station, TX (Ocean Drilling Program), 93100.

Linsley, B. K., Thunell, R. C., Morgan, C., and Williams, D. F., 1985. Oxygen minimum expansion in the Sulu Sea, western equatorial Pacific, during the last glacial low stand of sea level. Mar. Micropaleontol., 9:395-418.

Posamentier, H. W., Jervey, M. T., and Vail, P. R., 1988. Eustatic control on clastic deposition. I: conceptual framework. In Wilgus, C., Hastings, B. S., Kendall, C.G.S.C., Posamentier, H. W., 
Ross, C. A., and Van Wagoner, J. C. (Eds.), Sea-level Changes: An Integrated Approach: Spec. Publ. Soc. Econ. Paleontol. Mineral., 42:109-124.

Rangin, C., Silver, E. A., von Breymann, M. T., et al., 1990. Proc. ODP, Init. Repts., 124: College Station, TX (Ocean Drilling Program).

Reymer, J.J.G., Schlager, W., and Droxler, A. W., 1988. Site 632: Pliocene-Pleistocene sedimentation cycles in a Bahamian basin. In Austin, J. A., Jr., Schlager, W., et al., Proc. ODP, Sci. Results, 101: College Station, TX (Ocean Drilling Program), 213-220.

Stainforth, R. M., Lamb, J. L., Luterbacher, H. P., Beard, J. H., and Jeffords, R. M., 1975. Cenozoic planktonic foraminiferal zonation and characteristics of index forms. Univ. Kans. Paleontol. Contrib. Art., 62:1-425.

Toumarkine, M., and Luterbacher, H., 1985. Paleocene and Eocene planktic foraminifera. In Bolli, H. M., Saunders, J. B., and
Perch-Nielsen, K. (Eds.), Plankton Stratigraphy: Cambridge (Cambridge Univ. Press), 87-154.

van Andel, T. H., 1975. Mesozoic/Cenozoic calcite compensation depth and the global distribution of calcareous sediments. Earth Planet. Sci. Lett., 26:187-194.

Van Gorsel, J. T., and Troelstra, S. R., 1981. Late Neogene planktonic foraminiferal biostratigraphy and climatostratigraphy of the Solo River section (Java, Indonesia). Mar. Micropaleontol., 6:183-209.

Date of initial receipt: 11 July 1990

Date of acceptance: 10 February 1991

Ms 124B-130 